\title{
Pengaruh Penambahan RD 31 pada Beton dengan Substitusi Ground Granulated Blast Furnance Slag
}

\author{
ANNI SUSILOWATI, SERIN GINTING
}

Jurusan Teknik Sipil, Politeknik Negeri Jakarta

Email: anni.susilowati@sipil.pnj.ac.id

\begin{abstract}
ABSTRAK
Jauhnya lokasi batching plant dengan tempat penuangan kerapkali membuat beton setting sehingga dibutuhkan bahan tambah retarder. Ground Granulated Blast Furnace Slag (GGBFS) memiliki komposisi kimia mirip semen. Oleh karena itu, dilakukan penelitian penambahan retarder pada beton dengan substitusi GGBFS sebagai pengganti sebagian semen untuk mengetahui pengaruh (dengan uji regresi SPSS), sifat fisik dan mekanik beton, serta mendapatkan kadar optimum penambahan retarder. Metode penelitian ini menggunakan metode eksperimental dengan variasi campuran 90\% semen, 10\% GGBFS dengan retarder 0\%, 0,2\%, 0,4\%, dan 0,6\% berat semen dengan fas 0,5 sesuai SNI 03-2834-2000. Hasil penelitian menunjukkan retarder 0,2\% - 0,6\% mampu meningkatkan kuat tekan sebesar 19,61 - 50,59\%. Berdasarkan hasil penelitian diperoleh kadar optimum 0,2\% karena memiliki sifat paling baik.
\end{abstract}

Kata kunci: GGBFS, kuat tekan, retarder

\begin{abstract}
Long distance between batching plant to the pouring area often causes the concrete undergo a setting, so that a retarder addition material is needed. Ground Granulated Blast Furnace Slag (GGBFS) which has a chemical composition similar to cement. Therefore, a research was conducted on retarder addition to concrete with GGBFS substitution as a partial cement substitute to obtain the effect (regression analysis method in SPSS), physical and mechanical properties of concrete, and to obtain the optimum level of retarder addition. This research used an experimental method with a mixture variation of $90 \%$ cement, $10 \%$ GGBFS with retarder percentage as follows; $0 \%, 0.2 \%, 0.4 \%$, and $0.6 \%$ of cement weight with a water/cement is 0.5 according to SNI 03-2834-2000. The results of research with the addition of a retarder of $0.2 \%-0.6 \%$ were able to increase the compressive strength by $19.61-50.59 \%$. Based on the results, the optimum level of retarder is at a variation of $0.2 \%$ as it has the best physical and mechanical properties.
\end{abstract}

Keywords: GGBFS, compressive strength, retarder 


\section{PENDAHULUAN}

Kapitalisasi pasar konstruksi di Indonesia dari tahun ke tahun meningkat. Menurut data dari Asosiasi Semen Indonesia (ASI) penjualan semen meningkat sebesar 8,6\% dibanding tahun 2017. Pada tahun 2018, penjualan semen mencapai 75,2 juta ton, Hal ini menunjukan semakin meningkatnya penjualan semen. Produksi semen di dunia membutuhkan sekitar 3 milliar ton bahan baku setiap tahunnya (Bilim, C., Atis, D. C., Tanyildizi, H., \& Karahan, O., 2009) dan sekitar 2,5\% emisi total $\mathrm{CO}_{2}$ diseluruh dunia bersumber dari industri pabrik semen (Cakir, $\mathrm{O}$. \& Akoz, F., 2008). Dampak lingkungan terhadap emisi $\mathrm{CO}_{2}$ ini dapat diatasi dengan substitusi sebagian semen portland menggunakan granulated blast furnace slag (Arini et al., 2019). GGBFS merupakan GBFS yang dihaluskan, bersifat cementious, serta memiliki kandungan kimia yang mirip semen OPC, sehingga dapat digunakan sebagai bahan perekat agregat seperti semen pada umumnya (Saranya, P., Nagarajan, P., \& Shashikala, A. P., 2018). Kandungan kimia yang dominan dalam slag mengandung oksida besi dan silikat. Secara fisik dan kimia, slag mirip dengan terak tanur tinggi atau clinker. Blast Furnace Slag adalah kerak (slag), bahan sisa dari pengecoran besi (pig iron) (Syafitri, A., 2018). $\mathrm{SiO}_{2}, \mathrm{CaO}_{2}, \mathrm{AlO}_{3}$, dan $\mathrm{MgO}$ merupakan senyawa utama GGBFS dimana senyawa utamanya mirip dengan senyawa pembuatan semen (Turuallo, G., 2013). Meningkatnya penjualan semen juga menandakan bahwa meningkatnya produksi beton. Indonesia merupakan negara bertemperatur $30^{\circ} \mathrm{C}-$ $32^{\circ} \mathrm{C}$. Hal ini membuat beton cepat mengalami hardening, yang menyebabkan sukarnya penuangan dan penyelesaian, selain itu terlampau jauhnya jarak batching plant dengan proyek. Jika beton sudah mengalami setting sebelum penuangan, maka beton tersebut sudah tidak dapat dipakai dan akan menambah jumlah limbah beton yang dapat merusak kesuburan tanah dan ekosistem sekitarnya. Maka dari itu, dibutuhkan bahan tambah berupa retarder pada beton untuk menghindari terjadinya hal tersebut.

Hasil penelitian (Bakastri, A., 2019), penggunaan GGBFS sebagai bahan pengganti sebagian semen pada beton dengan kadar $10 \%$ menambah kuat tekan dan kuat belah beton masingmasing $12,72 \%$ dan $17,00 \%$ pada umur 28 hari. Dalam penelitian ini menyimpulkan bahwa penggunaan GGBFS dengan variasi $10 \%$ dapat diaplikasikan pada bangunan low rise building untuk elemen kolom dan balok. Persentase optimum retarder terdapat pada kadar $0,6 \%$ pada umur beton 28 hari dan menambah kuat tekan sebesar 6,24\% (Nurfitriani, N. \& Wibawa, T., 2019).

Berdasarkan latar belakang tersebut di atas, maka perlu dilakukan penelitian dengan judul "Pengaruh Penambahan Retarder pada Beton dengan Substitusi GGBFS penambahan GGBFS". Waktu setting pada beton akan bertambah karena penambahan GGBFS (Karim, G. A., Susilowati, E., \& Pratiwi, W., 2018). Kuat tekan beton dapat menurun apabila menggunakan retarder secara berlebihan pada campuran beton (Putra, F. Z., Prihantono, \& Murtinugraha, R. E., 2014) sehingga untuk menghindari hal tersebut digunakan GGBFS dan retarder. Kedua bahan ini cocok digunakan bila jarak antara batching plant dengan proyek sangat jauh. Berdasarkan penelitian di atas, kedua bahan ini juga menghasilkan kekuatan yang lebih kuat pada umur beton tertua, karena memiliki sifat yang sama diharapkan dapat menghasilkan sifat fisik dan mekanik beton yang lebih baik.

\section{METODE PENELITIAN}

Penelitian dilakukan di Laboratorium Uji Bahan Teknik Sipil Politeknik Negeri Jakarta yang dilaksanakan pada bulan April - Juli 2020.

Bahan yang digunakan pada penelitian ini adalah sebagai berikut:

(a) semen Tipe 1 (OPC);

RekaRacana: Jurnal Teknik Sipil - 192 
(b) agregat kasar butir maks 40 mm;

(c) agregat halus pasir bangka;

(d) GGBFS;

(e) retarder Naptha RD 31 (tipe D);

(f) air Laboratorium Bahan Teknik Sipil Politeknik Negeri Jakarta.

Metode penelitian yang dilakukan adalah metode eksperimental dengan membuat benda uji beton dengan faktor air semen sebesar 0,5. Variasi benda uji dengan perbandingan semen : GGBFS : retarder yaitu (90\%:10\%:0\%), (90\%:10\%:0,2\%), (90\%:10\%:0,4\%), (90\%:10\%:0,6\%) dari berat semen. Benda uji yang dibuat berbentuk silinder diameter $15 \mathrm{~cm}$ dan tinggi $30 \mathrm{~cm}$ dengan pengujian pada umur 7, 14, 21 dan 28 hari. Jumlah benda uji yang digunakan pada masing-masing pengujian berjumlah 3 silinder sehingga berjumlah 48 buah benda uji. Penelitian ini menggunakan metode mix design sesuai peraturan dan spesifikasi beton SNI 03-2834-2000 serta menggunakan software SPSS untuk menganalisa besarnya pengaruh penambahan retarder.

Berdasarkan mix design SNI 03-2834-2000 diperoleh kebutuhan bahan untuk $1 \mathrm{~m}^{3}$ yang disajikan pada Tabel $\mathbf{1}$ dan Tabel 2 sebagai berikut.

Tabel 1. Kebutuhan Bahan $1 \mathrm{~m}^{3}$ tanpa Retarder

\begin{tabular}{lcc}
\multicolumn{1}{c}{ Material } & Kebutuhan & Satuan \\
\hline Semen & 333 & $\mathrm{~kg}$ \\
\hline Air & 197,01 & liter \\
\hline Agregat Halus & 677,72 & $\mathrm{~kg}$ \\
\hline Agregat Kasar & $1.070,27$ & $\mathrm{~kg}$ \\
\hline GGBFS & 37 & $\mathrm{~kg}$ \\
\hline
\end{tabular}

Tabel 2. Kebutuhan Bahan $1 \mathbf{m}^{3}$ dengan Retarder

\begin{tabular}{lcccc} 
& $\begin{array}{c}\text { Retarder } \\
\mathbf{0 \%}\end{array}$ & $\begin{array}{c}\text { Retarder } \\
\mathbf{0 , 2} \%\end{array}$ & $\begin{array}{c}\text { Retarder } \\
\mathbf{0 , 4 \%}\end{array}$ & $\begin{array}{c}\text { Retarder } \\
\mathbf{0 , 6 \%}\end{array}$ \\
\hline Semen [kg] & 333 & 333 & 333 & 333 \\
\hline GGBFS [kg] & 37 & 37 & 37 & 37 \\
\hline Air [liter] & 197,01 & 187,16 & 187,16 & 187,16 \\
\hline Agregat Halus [kg] & 677,72 & 677,72 & 677,72 & 677,72 \\
\hline Agregat Kasar [kg] & $1.070,27$ & $1.070,27$ & $1.070,27$ & $1.070,27$ \\
\hline Retarder [ml] & 0 & 740 & 1.480 & 2.220
\end{tabular}

\section{HASIL DAN PEMBAHASAN}

Berdasarkan hasil pengujian agregat kasar dan halus diperoleh hasil pengujian yang disajikan pada Tabel 3 sebagai berikut.

Tabel 3. Hasil Pengujian Agregat

\begin{tabular}{lccc} 
Sifat Bahan & Satuan & $\begin{array}{c}\text { Agregat } \\
\text { Kasar }\end{array}$ & $\begin{array}{c}\text { Agregat } \\
\text { Halus }\end{array}$ \\
\hline Berat Jenis & & 2,36 & 2,60 \\
\hline Berat Jenis SSD & & 2,47 & 2,62 \\
\hline Penyerapan Air & $\%$ & 4,84 & 0,79 \\
\hline Berat Isi Padat & $\mathrm{kg} / \mathrm{m}^{3}$ & $1.485,1$ & $1.533,8$ \\
\hline Berat Isi Lepas & $\mathrm{kg} / \mathrm{m}^{3}$ & 1.330 & $1.524,98$ \\
\hline Voids Padat & $\%$ & 36,931 & 40,84 \\
\hline Voids Lepas & $\%$ & 43,518 & 41,18 \\
\hline
\end{tabular}


Tabel 3. Hasil Pengujian Agregat lanjutan

\begin{tabular}{lccc}
\hline \multicolumn{1}{c}{ Sifat Bahan } & Satuan & $\begin{array}{c}\text { Agregat } \\
\text { Kasar }\end{array}$ & $\begin{array}{c}\text { Agregat } \\
\text { Halus }\end{array}$ \\
\hline Kadar Air & $\%$ & 1,64 & 5,16 \\
\hline Kadar Lumpur & $\%$ & 0,93 & 1,32 \\
\hline Analisa Ayak & $\%$ & 40 & Zona 2 \\
\hline Fineness Modulus (FM) & $\mathrm{mm}$ & 7,46 & 2,71 \\
\hline
\end{tabular}

\subsection{Sifat Fisik Beton}

\subsubsection{Pengujian slump}

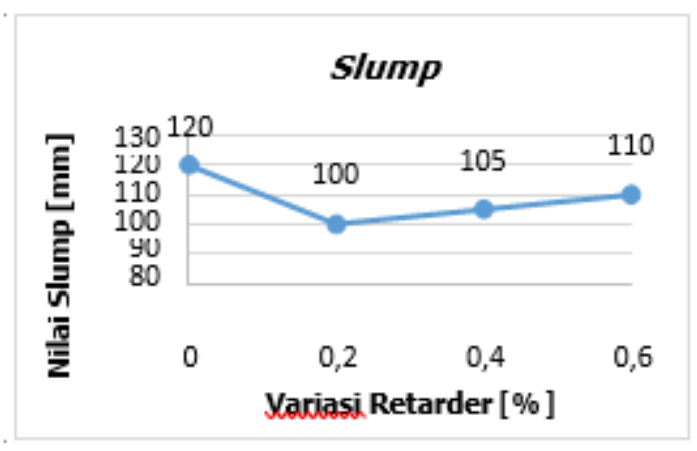

Gambar 1. Grafik hasil pengujian slump

Berdasarkan Gambar 1, nilai slump tanpa retarder menghasilkan nilai s/ump tertinggi yaitu $120 \mathrm{~mm}$. Kemudian nilai s/ump menurun sebesar $16,67 \%$ ketika ditambahkan retarder $0,2 \%$ menjadi $100 \mathrm{~mm}$ yang merupakan nilai slump terendah. Nilai slump mengalami penurunan karena retader yang digunakan berifat water reducer, tetapi setelah itu nilai slump terus naik seiring dengan penambahan jumlah retarder. Penambahan retarder dengan kadar $0,4 \%$ naik sebesar $12,50 \%$. Penambahan retarder sebesar $0,6 \%$ naik $8,33 \%$. Nilai s/ump yang dihasilkan pada masing-masing variasi memperoleh nilai s/ump yang sesuai dengan perencanaan yaitu 60 - $180 \mathrm{~mm}$. Untuk mengetahui besar pengaruh retarder terhadap nilai slump, akan dilanjutkan analisis dengan regresi nonlinear quadratic menggunakan software SPSS dengan hasil seperti Gambar 2 sebagai berikut.

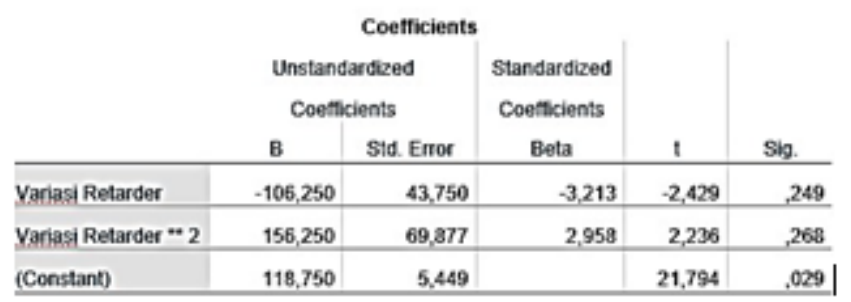

Gambar 1. Coefficients nilai slump

Berdasarkan Gambar 2 didapatkan nilai constant yang merupakan nilai slump sebesar 118,750 . Nilai sebesar 118,750 didapatkan jika tidak adanya pencampuran retarder, sedangkan untuk nilai $b$ yang merupakan variasi retarder pangkat satu diperoleh sebesar 106,250 serta untuk variasi retarder pangkat dua diperoleh sebesar 156,250. Hal ini menunjukkan bahwa koefisien regresi berpengaruh fluktuatif, yaitu naik dan turunnya bergantung pada besarnya variasi retarder yang ditambahkan. Sehingga dapat dituliskan ke dalam Persamaan 1, Persamaan 2 dan Persamaan 3 regresi nonlinear quadratic sebagai berikut. 


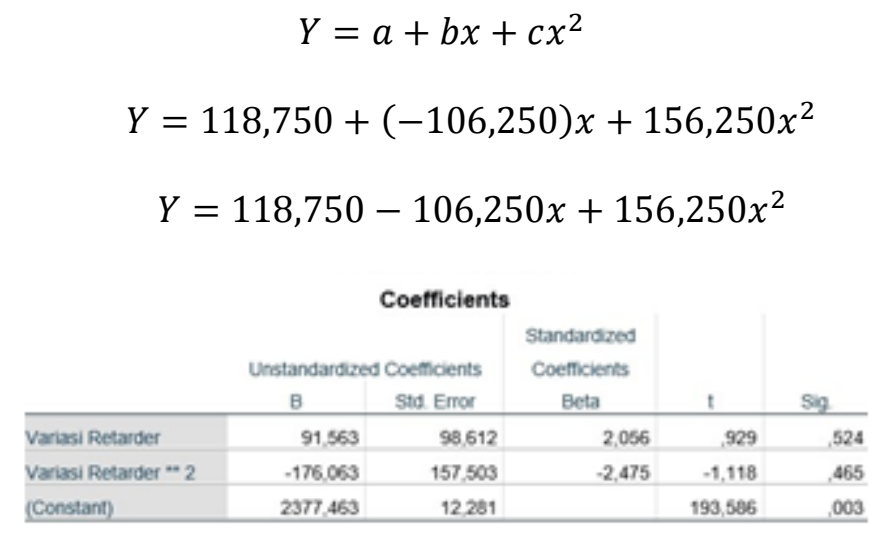

Gambar 3. Model summary nilai s/ump

Berdasarkan Gambar 3 menunjukkan bahwa penggunaan variasi retarder berpengaruh besar terhadap nilai s/ump. Hal ini dapat terlihat dari nilai $R$ square sebesar 0,857 ; yang berarti bahwa variasi retarder berpengaruh sebesar $85,7 \%$ terhadap nilai s/ump.

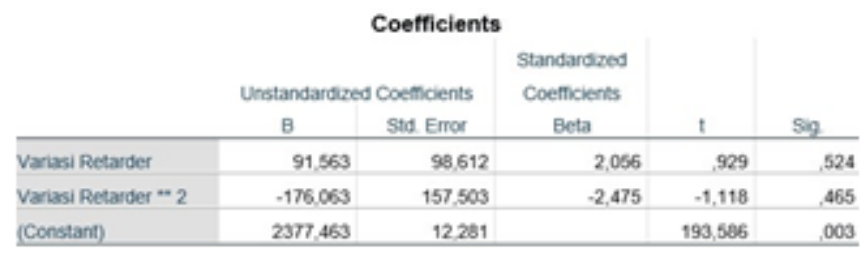

Gambar 4. ANOVA nilai slump

Berdasarkan Gambar 4, diperoleh nilai signifikansi sebesar 0,378. Nilai signifikansi yang diperoleh lebih dari 0,05; hal ini menunjukkan bahwa variasi retarder tidak berpengaruh secara signifikan terhadap nilai slump.

\subsubsection{Pengujian berat isi beton}

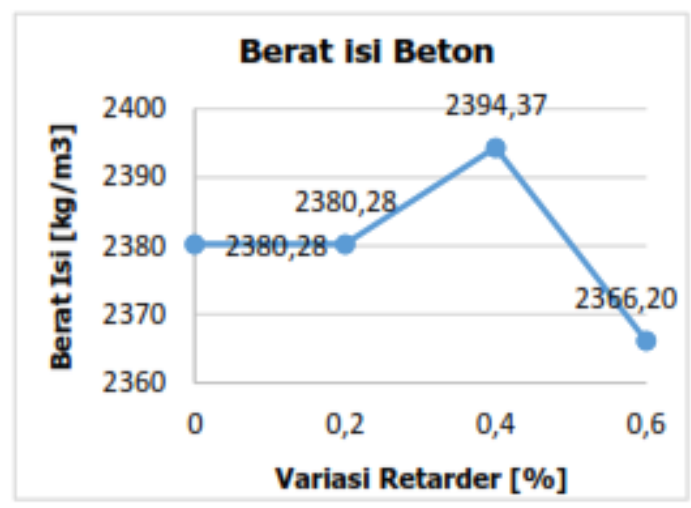

Gambar 5. Grafik hasil pengujian berat isi beton segar

Pada Gambar 5, menunjukkan perbandingan berat isi beton yang konstan kemudian naik lalu turun. Berat isi terbesar dicapai oleh variasi retarder $0,4 \%$ sebesar $2.394,37 \mathrm{~kg} / \mathrm{m}^{3}$ dan berat isi terendah ada pada variasi retarder $0,6 \%$ sebesar $2.366,20 \mathrm{~kg} / \mathrm{m}^{3}$. Variasi retarder $0,2 \%$ $0,4 \%$ mengalami peningkatan berat isi sebesar $0,59 \%$, kemudian pada variasi retarder $0,6 \%$ berat isi menurun sebesar $1,18 \%$. Dari hasil pengujian berat isi, rata-rata yang dihasilkan sebesar $2.380,28 \mathrm{~kg} / \mathrm{m}^{3}$; naik sebesar $2,74 \%$ dari berat isi perencanaan. Berdasarkan SNI 03- 
$2834-2000$ beton normal mempunyai berat isi $2.200-2.500 \mathrm{~kg} / \mathrm{m}^{3}$. sehingga rata-rata dari hasil pengujian termasuk berat isi beton normal. Untuk mengetahui besar pengaruh retarder terhadap berat isi beton, akan dilanjutkan analisis dengan regresi nonlinear quadratic menggunakan software SPSS dengan hasil seperti Gambar $\mathbf{6}$ sebagai berikut.

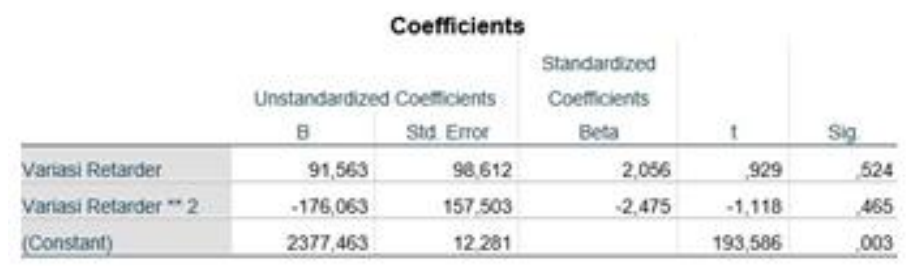

Gambar 6. Coefficients berat isi

Berdasarkan Gambar 6, didapatkan nilai constant yang merupakan nilai berat isi sebesar $2.377,463$. Nilai $b$ yang merupakan variasi retarder pangkat satu diperoleh sebesar 91,563 serta untuk variasi retarder pangkat dua diperoleh sebesar $-176,063$. Hal ini menunjukkan bahwa koefisien regresi berpengaruh fluktuatif, yaitu naik dan turunnya bergantung pada besarnya variasi retarder yang ditambahkan. Sehingga dapat dituliskan ke dalam Persamaan 4, Persamaan 5 dan Persamaan 6 regresi nonlinear quadratic sebagai berikut.

$$
\begin{aligned}
& Y=a+b x+c x^{2} \\
& Y=2.377,463+91,563 x+(-176,063) x^{2} \\
& Y=2.377,463+91,563 x-176,063 x^{2} \\
& \begin{array}{r|r|r|r} 
& \multicolumn{3}{c}{\text { Model Summary }} \\
\text { Adjusted R } & \text { Std. Error of the } \\
\text { R } & \text { R Square } & \multicolumn{1}{c}{\text { Square }} & \text { Estimate } \\
\hline, 775 & , 600 & -, 200 & 12,600 \\
\hline
\end{array}
\end{aligned}
$$

The independent variable is Variasi Retarder.

\section{Gambar 7. Model summary berat isi}

Berdasarkan Gambar 7, menunjukkan nilai $R$ square sebesar 0,600; yang berarti bahwa variasi retarder berpengaruh sebesar $60 \%$ terhadap berat isi.

\begin{tabular}{l|r|r|r|r|r} 
& \multicolumn{7}{c}{ ANOVA } & & \\
& Sum of Squares & of & Mean Square & \multicolumn{1}{l}{ F } & Siq. \\
\hline Regression & 238,006 & 2 & 119.004 & .750 & .653 \\
\hline Residual & 158,766 & 1 & 158,766 & & \\
\hline Total & 396,774 & 3 & & & \\
\hline The independent variable is Variasi Retarder. & & & & \\
\hline
\end{tabular}

\section{Gambar 8. ANOVA berat isi}

Berdasarkan Gambar 8, diperoleh nilai signifikansi sebesar 0,633. Nilai signifikansi yang diperoleh lebih dari 0,05; hal ini membuktikan bahwa variasi retardertidak berpengaruh secara signifikan terhadap berat isi. 


\subsubsection{Pengujian waktu ikat}

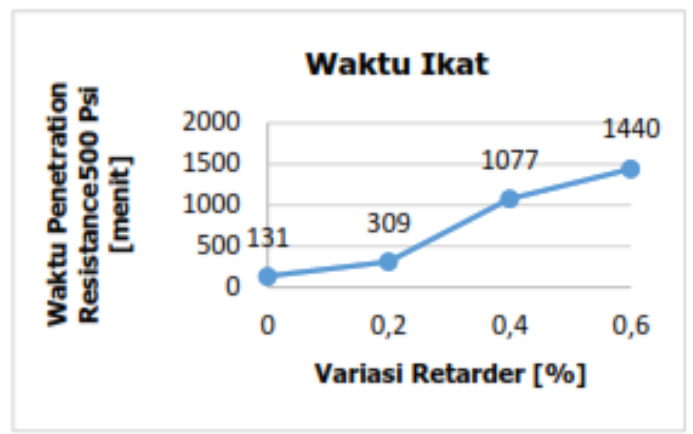

\section{Gambar 9. Grafik hasil pengujian waktu ikat}

Berdasarkan Gambar 9 dapat dilihat bahwa waktu ikat cenderung naik seiring dengan pertambahan retarder. Hal ini membuktikan bahwa bahan tambah yang digunakan bekerja sesuai dengan fungsinya yaitu memperlambat waktu setting pada beton segar. Waktu ikat tercepat dicapai oleh variasi $0 \%$ yaitu 131 menit; disusul oleh variasi 0,2\% sebesar 309 menit; kemudian pada variasi $0,4 \%$ sebesar 1.077 menit; lalu waktu ikat terbesar dicapai oleh variasi dengan kadar retarder terbanyak yaitu variasi $0,6 \%$ sebesar 1.440 menit. Untuk mengetahui seberapa besar pengaruh variasi retarderterhadap waktu ikat akan dilanjutkan analisis dengan regresi linear sederhana pada software SPSS yang dapat terlihat pada Gambar 10 sebagai berikut.

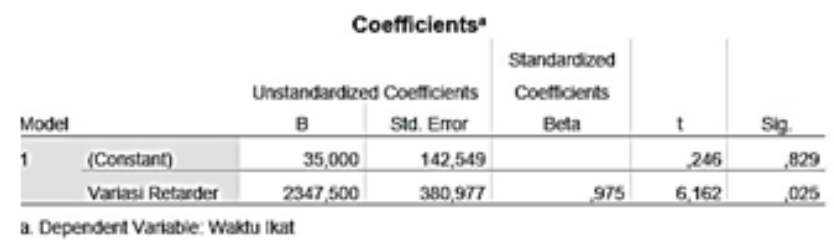

Gambar 10. Coefficients waktu ikat

Berdasarkan Gambar 10 didapatkan nilai constant yang merupakan nilai waktu ikat sebesar 35,000 . Untuk nilai $b$ yang merupakan variasi retarder sebesar $2.347,500$. Hal ini menunjukkan bahwa koefisien regresi berpengaruh positif yang menyatakan bahwa semakin tinggi penambahan variasi retardermenyebabkan waktu ikat beton segar semakin besar. Sehingga dapat dituliskan ke dalam Persamaan 7 dan Persamaan 8 regresi linear sederhana sebagai berikut.

$$
\begin{gathered}
Y=a+b x \\
Y=2.352,512+2.347,500 x
\end{gathered}
$$

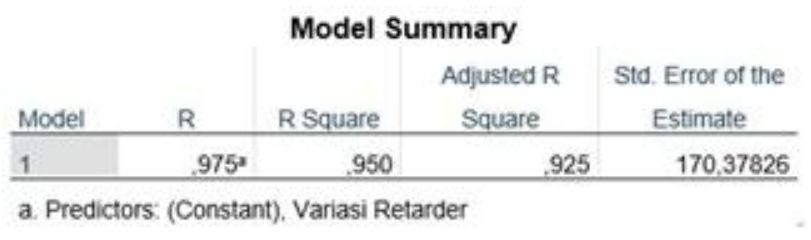

Gambar 11. Model summary waktu ikat

Berdasarkan Gambar 11, menunjukkan penggunaan variasi pengganti sebagian semen dengan GGBFS dan dan bahan tambah retarder berpengaruh kuat terhadap terhadap waktu ikat beton. 
Didapat nilai $R$ square sebesar 0,950; yang berarti penggunaan variasi pengganti sebagian semen dengan GGBFS $10 \%$ dan retarder berpengaruh sebesar $95 \%$ terhadap waktu ikat beton.

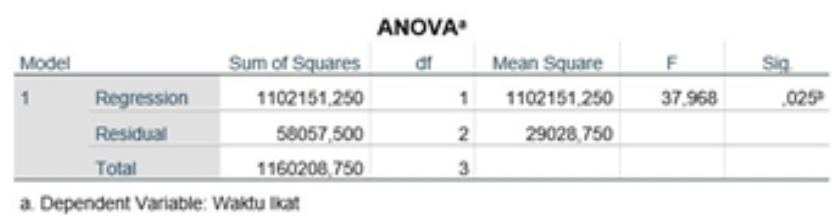

Gambar 12. ANOVA waktu ikat

Berdasarkan Gambar 12 nilai signifikansi sebesar 0,025. Nilai signifikansi yang diperoleh 0,025 $<0,05$; menunjukkan penggunaan variasi pengganti sebagian semen dengan GGBFS dan retarder berpengaruh secara signifikan terhadap waktu ikat beton segar.

\subsection{Sifat Mekanik Beton}

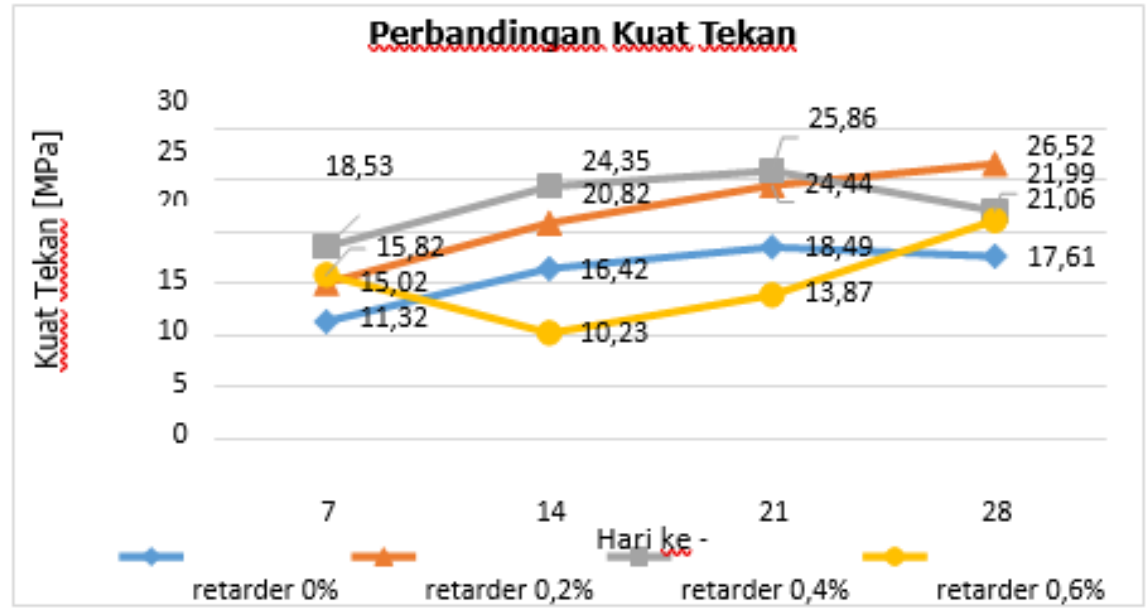

Gambar 13. Grafik perbandingan hasil kuat tekan

Berdasarkan Gambar 13, nilai kuat tekan dengan penambahan retarder $0,2 \%$ menunjukkan grafik yang terus meningkat seiring dengan bertambahnya umur beton. Pada varisi $0,2 \%$ didapatkan kuat tekan tertinggi yaitu sebesar 26,52 MPa dengan peningkatan sebesar $19,61 \%$ - 50,59\% dibandingkan dengan beton tanpa retarder. Kuat tekan beton umur 28 hari dengan substitusi GGBFS 10\% tanpa retarder mencapai 31,59 MPa (Bakastri, A., 2019). Pada penelitian ini kuat tekan yang dihasilkan menurun sebesar $13,31 \%$ jika dibandingkan dengan penelitian tersebut. Hal ini disebabkan karena adanya pengaruh penambahan retarderpada campuran beton. Hasil penelitian terdahulu, didapatkan kadar optimum penambahan retarder terdapat pada variasi $0,6 \%$ dengan kuat tekan sebesar 22,013 MPa dan mengalami peningkatan kuat tekan sebesar 6,24\% (Nurfitriani, N. \& Wibawa, T., 2019). Pada penelitian ini kuat tekan yang dihasilkan naik sebesar $16,99 \%$ jika dibandingkan dengan penelitian tersebut. Dosis yang paling ideal untuk pembahan bahan tambah pada campuran beton adalah pada dosis 0,2 liter/100 kg berat semen (Sutandar, E., 2014). Hal ini terlihat pada umur awal beton dan pada umur 28 hari kekuatannya semakin meningkat dan lebih besar dari pada beton normal tanpa bahan kimia tambahan.

Untuk mengetahui seberapa besar pengaruh penambahan retarder terhadap kuat tekan beton pada umur 7, 14, 21 dan 28 hari akan dilakukan analisa dengan menggunakan regresi nonlinear quadratic dengan sofware SPSS sebagai berikut. 


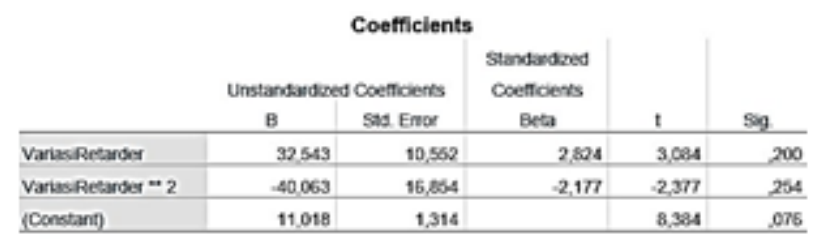

\section{Gambar 14. Coefficients kuat tekan 7 hari}

Berdasakan Gambar 14 didapatkan output SPSS untuk kuat tekan 7 hari. Nilai constant yang merupakan nilai kuat tekan sebesar 11,018 . Nilai $\boldsymbol{b}$ yang merupakan variasi retarderpangkat satu diperoleh sebesar 32,543 serta untuk variasi retarderpangkat dua diperoleh sebesar 40,063 . Hal ini menunjukkan bahwa koefisien regresi berpengaruh fluktuatif, yaitu naik dan turunnya bergantung pada besarnya variasi retarder yang ditambahkan.

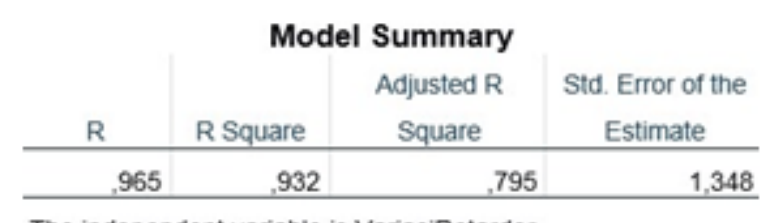

The independent variable is VariasiRetarder.

\section{Gambar 15. Model summary kuat tekan 7 hari}

Gambar 15, menunjukkan penggunaan variasi pengganti sebagian semen dengan GGBFS dan bahan tambah retarder berpengaruh kuat terhadap terhadap kuat tekan 7 hari. Didapat nilai $\boldsymbol{R}$ square sebesar 0,932; yang berarti penggunaan variasi pengganti sebagian semen dengan GGBFS $10 \%$ dan retarder berpengaruh sebesar 93,2\% terhadap kuat tekan 7 hari.

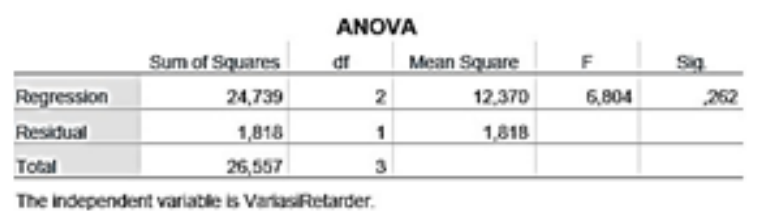

Gambar 16. ANOVA kuat tekan 7 hari

Gambar 16 nilai signifikansi sebesar 0,262. Nilai signifikansi yang diperoleh 0,262 > 0,05; menunjukkan penggunaan variasi pengganti sebagian semen dengan GGBFS dan retarder tidak berpengaruh secara signifikan terhadap kuat tekan beton umur 7 hari.

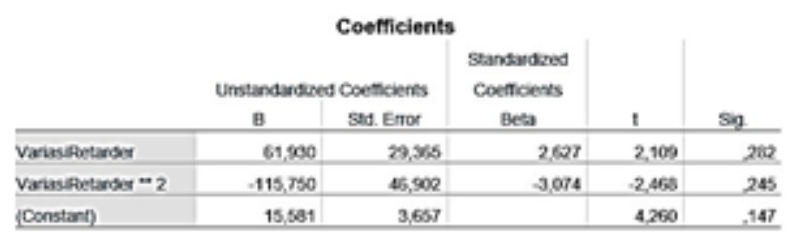

\section{Gambar 17. Coefficients kuat tekan 14 hari}

Berdasakan Gambar 17 didapatkan output SPSS untuk kuat tekan 14 hari. Nilai constant yang merupakan nilai kuat tekan sebesar 15,561 . Nilai $\boldsymbol{b}$ yang merupakan variasi retarder pangkat satu diperoleh sebesar 61,930 serta untuk variasi retarder pangkat dua diperoleh sebesar $-115,750$. Hal ini menunjukkan bahwa koefisien regresi berpengaruh fluktuatif, yaitu naik dan turunnya bergantung pada besarnya variasi retarder yang ditambahkan. 


\begin{tabular}{|c|c|c|c|}
\hline \multicolumn{4}{|c|}{ Model Summary } \\
\hline $\mathrm{R}$ & R Square & $\begin{array}{c}\text { Adjusted R } \\
\text { Square }\end{array}$ & $\begin{array}{c}\text { Std. Error of the } \\
\text { Estimate }\end{array}$ \\
\hline ,935 & 873 & 620 & 3,752 \\
\hline
\end{tabular}

\section{Gambar 18. Model summary kuat tekan 14 hari}

Gambar 18, menunjukkan penggunaan variasi pengganti sebagian semen dengan GGBFS dan bahan tambah retarder berpengaruh kuat terhadap terhadap kuat tekan 14 hari. Didapat nilai $\boldsymbol{R}$ square sebesar 0,873; yang berarti penggunaan variasi pengganti sebagian semen dengan GGBFS $10 \%$ dan retarder berpengaruh sebesar $87,3 \%$ terhadap kuat tekan 14 hari.

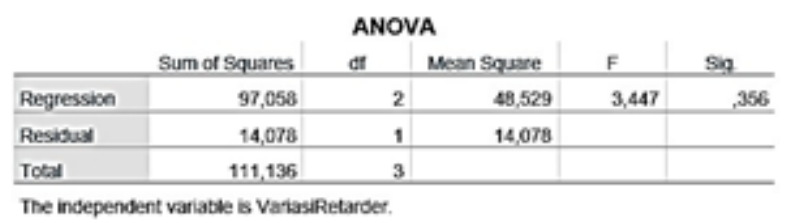

Gambar 19. ANOVA kuat tekan 14 hari

Gambar 19 nilai signifikansi sebesar 0,356. Nilai signifikansi yang diperoleh 0,356 > 0,05; menunjukkan penggunaan variasi pengganti sebagian semen dengan GGBFS dan retarder tidak berpengaruh secara signifikan terhadap kuat tekan beton umur 14 hari.

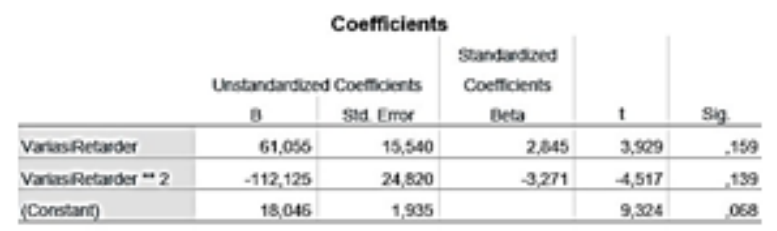

\section{Gambar 20. Coefficients kuat tekan 21 hari}

Berdasakan Gambar 20 didapatkan output SPSS untuk kuat tekan 21 hari. Nilai constant yang merupakan nilai kuat tekan sebesar 18,046 . Nilai $\boldsymbol{b}$ yang merupakan variasi retarder pangkat satu diperoleh sebesar 61,056 serta untuk variasi retarderpangkat dua diperoleh sebesar $-112,125$. Hal ini menunjukkan bahwa koefisien regresi berpengaruh fluktuatif, yaitu naik dan turunnya bergantung pada besarnya variasi retarder yang ditambahkan.

\begin{tabular}{r|r|r|r} 
& \multicolumn{3}{c}{ Model Summary } \\
Adjusted R \\
R & R Square & Square & $\begin{array}{c}\text { Std. Error of the } \\
\text { Estimate }\end{array}$ \\
\hline .978 & .957 & .872 & 1,986 \\
\hline
\end{tabular}

The independent variable is VariasiRetarder.

Gambar 21. Model summary kuat tekan 21 hari

Gambar 21, menunjukkan penggunaan variasi pengganti sebagian semen dengan GGBFS dan bahan tambah retarder berpengaruh kuat terhadap terhadap kuat tekan 21 hari. Didapat nilai $\boldsymbol{R}$ square sebesar 0,957 yang berarti penggunaan variasi pengganti sebagian semen dengan GGBFS $10 \%$ dan retarder berpengaruh sebesar 95,7\% terhadap kuat tekan 21 hari. 


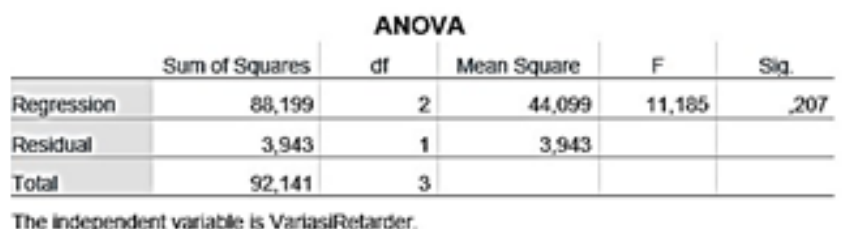

Gambar 22. ANOVA kuat tekan 21 hari

Gambar 22 nilai signifikansi sebesar 0,207. Nilai signifikansi yang diperoleh 0,207 > 0,05; menunjukkan penggunaan variasi pengganti sebagian semen dengan GGBFS dan retarder tidak berpengaruh secara signifikan terhadap kuat tekan beton umur 21 hari.

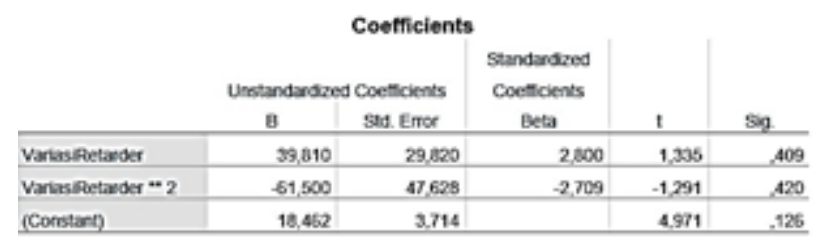

\section{Gambar 23. Coefficients kuat tekan 28 hari}

Berdasakan Gambar 23 didapatkan output SPSS untuk kuat tekan 28 hari. Nilai constant yang merupakan nilai kuat tekan sebesar 18,462 . Nilai $\boldsymbol{b}$ yang merupakan variasi retarder pangkat satu diperoleh sebesar 39,810 serta untuk variasi retarderpangkat dua diperoleh sebesar -61,500. Hal ini menunjukkan bahwa koefisien regresi berpengaruh fluktuatif, yaitu naik dan turunnya bergantung pada besarnya variasi retarder yang ditambahkan.

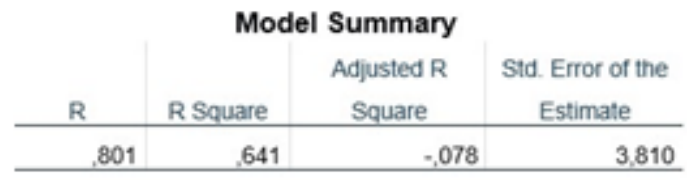

The independent variable is VariasiRetarder

\section{Gambar 24. Model summary kuat tekan 28 hari}

Gambar 24, menunjukkan penggunaan variasi pengganti sebagian semen dengan GGBFS dan bahan tambah retarder berpengaruh kuat terhadap terhadap kuat tekan 28 hari. Didapat nilai $\boldsymbol{R}$ square sebesar 0,641 yang berarti penggunaan variasi pengganti sebagian semen dengan GGBFS $10 \%$ dan retarder berpengaruh sebesar 64,1\% terhadap kuat tekan 28 hari.

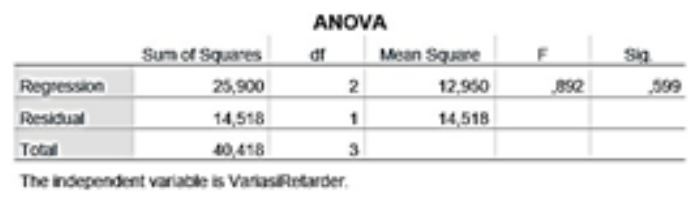

Gambar 25. ANOVA kuat tekan 28 hari

Gambar 25 nilai signifikansi sebesar 0,599. Nilai signifikansi yang diperoleh 0,599 > 0,05; menunjukkan penggunaan variasi pengganti sebagian semen dengan GGBFS dan retarder tidak berpengaruh secara signifikan terhadap kuat tekan beton umur 28 hari. 
Berdasarkan output SPSS didapatkan rekapitulasi hasil pengujian kuat tekan beton yang disajikan pada Tabel 4 sebagai berikut.

Tabel 4. Rekapitulasi Output SPSS Pengujian Kuat Tekan Beton

\begin{tabular}{lcccc}
\multicolumn{1}{c}{ Pengujian } & Sig. & Persamaan & Keterangan \\
\hline Kuat Tekan 7 Hari & 0,262 & $Y=11,018+32,543 x-40,063 x^{2}$ & tidak berpengaruh \\
\hline Kuat Tekan 14 Hari & 0,356 & $Y=15,581+61,930 x-115,750 x^{2}$ & tidak berpengaruh \\
\hline Kuat Tekan 21 Hari & 0,207 & $Y=18,046+61,055 x-112,125 x^{2}$ & tidak berpengaruh \\
\hline Kuat Tekan 28 Hari & 0,599 & $Y=18,462+39,810 x-61,500 x^{2}$ & tidak berpengaruh \\
\hline
\end{tabular}

Berdasarkan Gambar 14, Gambar 17, Gambar 20 dan Gambar 23 Coefficients pada masing-masing umur beton, maka dapat disimpulkan bahwa koefisien nilai $b$ bersifat fluktuatif, sehingga turun naiknya grafik bergantung pada besarnya penambahan retarder (nilai $x$ ).

\section{KESIMPULAN}

Pada umur 28 hari, penambahan retardersebesar 0,2\% - 0,6\% mampu meningkatkan kuat tekan sebesar $19,61 \%-50,59 \%$. Berdasarkan hasil pengujian yang telah dilakukan diperoleh kadar optimum penambahan retarder dengan substitusi GGBFS $10 \%$ pada beton adalah $0,2 \%$ yaitu sebesar 26,52 MPa karena memiliki sifat fisik dan mekanik yang paling baik. Pada penelitian selanjutnya diharapkan untuk tidak menggunakan retarder lebih dari 0,6\% karena lamanya waktu ikat yang dihasilkan.

\section{UCAPAN TERIMA KASIH}

Penulis mengucapkan terima kasih kepada Unit Penelitian dan Pengabdian Masyarakat Politeknik Negeri Jakarta yang telah memberikan pendanaan sehingga penelitian tugas akhir ini dapat dilaksanakan.

\section{DAFTAR RUJUKAN}

Arini, R.N., Sipil, T., Pancasila, U., Warastuti, N., Sipil, T., Pancasila, U., ... Pancasila, U. (2019). Analisis Kuat Tekan Dengan Aplikasi Ground Granulated Blast Furnace Slag Sebagai Pengganti Semen Pada Campuran. Jurnal Konstruksia, 10(2), 89-94.

Badan Standardisasi Nasional. (2000). SNI 03-2834-2000 tentang Tata Cara Pembuatan Rencana Campuran Beton Normal. Jakarta: Badan Standardisasi Nasional.

Bakastri, A. (2019). Penggunaan GGBFS Sebagai Bahan Pengganti Sebagian Semen Pada Beton. Tugas Akhir. Jakarta: Politeknik Negeri Jakarta.

Bilim, C., Atis, D. C., Tanyildizi, H., \& Karahan, O. (2009). Predicting the compressive strength of ground granulated blast furnace slag concrete using artificial neural network. Advances in Engineering Software, 40(5), 334-340.

Cakir, O. \& Akoz, F. (2008). Effect of curing conditions on the mortars with and without GGBFS. Construction and Building Materials, 22(3), 308-314.

Karim, G. A., Susilowati, E., \& Pratiwi, W. (2018). Pengaruh Ground Granulated Blast Furnace Slag Terhadap Sifat Fisika Semen Portland. Jurnal Teknologi Bahan dan Barang Teknik, $8(2), 47-52$.

Nurfitriani, W. \&. (2019). Kualitas Beton Normal Dengan Penambahan Retarder. Tugas Akhir. Jakarta: Politeknik Negeri Jakarta.

Putra, F. Z., Prihantono \& Murtinugraha, R. E. (2014). Studi Kuat Tekan Beton yang Mengalami Penundaan Penuangan dengan Penambahan Bahan Tambah Retarder. Jurnal Menara Jurnal Teknik Sipil FT UNJ, 9(2), 31-40. 
Saranya, P., Nagarajan, P., \& Shashikala, A. P. (2018). Eco-friendly GGBS Concrete: A Stateof-The-Art Review. IOP Conference Series Materials Science and Engineering, 330(1), 012057.

Sutandar, E. (2014). Dosis Penggunaan Bahan Tambah Kimia (Chemical Admixture) Pada Campuran Beton Normal. Vokasi, X(1), 6-14.

Syafitri, A. (2018). Optimasi Slag Cement Pada Kekuatan Lentur Beton Mutu Tinggi Dengan Berbagai Perawatan. Tugas Akhir. Medan: Universitas Sumatera Utara.

Turuallo, G. (2013). Kinerja Ground Granulated Blast Furnage Slag (GGBFS) Sebagai Bahan Pengganti Sebagian Semen Untuk Sustainable Development. Seminar Nasional "Inovasi Teknologi Berwawasan Lingkungan Dalam Pembangunan Infrastruktur Wilayah dan Industri" dalam Rangka Peringatan Pendidikan Keteknikan Di Propinsi Sulawesi Tengah, 22 Oktober 2013 (p. __). Palu: Universitas Tadulako. 